\title{
DESIGN AND PERFORMANCE EVALUATION OF SUPPLEMENTAL AIR SUPPLIED CHARCOAL STOVE
}

\author{
BELLO R. S. ${ }^{1{ }^{*}}$, ONILUDE M. A. ${ }^{2 b}$, ADEGBULUGBE T. A. ${ }^{3 c}$ \\ ${ }^{1}$ Department of Agricultural \& Bio-Environmental Engineering Technology, Federal College of \\ Agriculture, Ishiagu, Ebonyi State \\ ${ }^{2}$ Department of Agricultural \& Environmental Engineering, University of Ibadan, Nigeria \\ ${ }^{3}$ Department of Agricultural Engineering Technology, Federal College of Agriculture, Moor \\ Plantation, Ibadan, Nigeria \\ E-mail address: ${ }^{a^{*}}$ segemi2002@gmail.com ${ }^{\mathrm{b}}$ ma.onilude@mail.ui.edu.ng, \\ 'thomasadegbulugbe@yahoo.com
}

Keywords: Charcoal, stove, supplemental air, efficiency, emissions

\begin{abstract}
Improved charcoal stoves are known to generally develop high thermal efficiencies, but most generate appreciable level of gas emissions which has made them unsuitable for use within residential buildings. In order to eliminate this constraint, a supplemental air supply power pack was introduced to improve charcoal stove thermal and aesthetic performance. This paper described the experimental setup, test procedures and results showing optimized performance. Comparison between performance characteristics shows the air aspirated stove and other improved charcoal stove showed more than $20 \%$ increased efficiency, power input of $2.26 \mathrm{~kW}(0.691 \mathrm{KW} / \mathrm{hr})$ and overall thermal efficiency of $36.74 \%$ for the improved stove, the stove is thermally efficient more than the traditional stove.
\end{abstract}

\section{INTRODUCTION}

Cookstove development has been an age long art since the stone ages when fire was ignited with striking of two stones against each other to produce fire [1]. The slow but progressive development of stove technology from the traditional 3-stone fire and mud stoves to improved cookstove technologies and the gasifier stoves had revolutionized the industry and increased awareness in its further development. Literature reports of stoves available locally do not at the moment represent the best designs modern engineering can offer [2, 3]. However, the increasing interest on issues of climate change and global warming has created awareness on the environmental and social costs of using traditional fuels and stoves nowadays. Research results so far showed that one stove may be efficient, another may heat faster, another safer, and each of them pollutes more or less than the other [4]. It therefore depends on the stove designer to pick out a design that best suits the locality and food types for which it is intended.

There exists a wide range of fuel used in cookstoves from firewood to biomass material resources, to liquid fuel and fossil materials. Research results showed varied performance characteristics of different fuel under different operating condition based on such performance indicators as time spent in cooking $1 \mathrm{~kg}$ of food material, specific fuel consumption values, burn rates, thermal efficiency, among several other factors. Another critical indicator of stove efficiency is the emission factor which became a topical factor in the 1980s [1]. Emissions of most concern are particulate matter $(\mathrm{PM})$, polycyclic organic matter $(\mathrm{POM})$ and carbon monoxide $(\mathrm{CO})$ emissions. The report of ISO/DIS 13336, [2] pointed out two issues of particular concern (variability in emission control performance of wood stoves operated at homes and laboratory and the use of wood and biomass materials in residential homes). These issues and its cause-and-effect relationships are difficult to quantify due to the large number of interrelated variables associated with them. 
Significant progress has been made toward cookstove designs with reduced emissions and increased efficiency [5, 6, 7, 8, 9, and 10]. However, further reductions in emissions are required to meet WHO guidelines for indoor air quality (IAQ) $[11,3]$ to achieve significant health benefits.

Emissions in cookstove are traceable to poor or inadequate air supply to support burning. Common practice in traditional 3-stone and mud stove cooking involves fanning with leaves and lightweight materials to increase air supply. This work therefore seeks to increase secondary air supply to combustion chamber to increase oxygen supply to support burning in an improved charcoal stove. This research equally seeks to optimize the stove performance by incorporating a rechargeable DC power pack for continuous fan operation that could last the coking period.

\section{MATERIALS AND METHOD}

\section{Experimental stove description and design}

In order to make charcoal stove more attractive and competitive to deliver high thermal value to the cooking pot, convenient to use, environment friendly and cheap, a fan aspirated charcoal-fired stove was developed. This is especially important in Nigeria where charcoal stoves and firewood stoves are popular and available at very low costs but with very low thermal (heating) values. In order to further improve performance, an artificial airflow device was incorporated.

\section{Design equations}

In the design of the stove, the power output desired, appropriate size of the stove and other important parameters estimated by computation are taken into consideration

Stove heat energy requirement: The amount of heat required to be supplied by the stove was determined using equation 1 based on the amount of food to be cooked and/or water to be boiled and their corresponding specific heat energy [12].

$Q_{n}=\frac{M_{f} \times E_{s}}{T}$

Where:

$Q_{n}=$ energy requirement, $\mathrm{Kcal} / \mathrm{hr}, M_{f}=$ mass of food, $\mathrm{kg}, E_{s}=$ specific energy, $\mathrm{KCal} / \mathrm{kg}, \mathrm{T}=$ cooking time, $\mathrm{hr}$

Airflow rate required for combustion was estimated to determine the size of the fan required. The airflow per unit mass of fuel is dependent on the stoichiometric air (theoretical air) required to burn the charcoal. Air flow rate can be computed using equation 2.

$A F R=\frac{\varepsilon \times F C R \times S A}{\rho_{a}}$

Where:

$\mathrm{AFR}=$ air flow rate, $\mathrm{m}^{3} / \mathrm{hr}$

$\varepsilon=$ equivalence ratio, 0.3 to 0.4

$\mathrm{FCR}=$ rate of consumption of fuel, $\mathrm{kg} / \mathrm{hr}$

$\mathrm{SA}=$ stoichiometric air of charcoal is $7.1 \mathrm{~kg}$ of air for $1 \mathrm{~kg}$ of Coal [13]

$\rho_{a}=$ air density, $1.25 \mathrm{~kg} / \mathrm{m}^{3}$

A preliminary test using traditional test stove was conducted to determine the fuel consumption rate $(0.40 \mathrm{~kg} / \mathrm{hr})$ and the amount of fuel consumed $(0.38 \mathrm{~kg})$. Using an equivalent ratio of 0.4 , the air flow rate estimated using equation 3 is $0.35 \mathrm{~m}^{3} / \mathrm{hr}$. The superficial air velocity within the fuel is computed using the formula, 
$V_{s}=\frac{A F R}{\text { Area of inner combustion chamber }}$

Where:

$V_{s}=$ superficial gas velocity, $\mathrm{m} / \mathrm{s}$

AFR $=$ air flow rate, $\mathrm{m}^{3} / \mathrm{hr}$

The choice of size of the combustion chamber dimensions between 95 and $105 \mathrm{~mm}$ and the superficial velocity of $0.05 \mathrm{~m} / \mathrm{s}$ for was made considering literature studies on gasifier stove design and testing to meet the objectives of power, burn time, and minimum emission of particulate matter. The resistance to airflow exerted by fuel and ash inside the combustion chamber during burning was evaluated using the expression,

$R_{f}=T_{f} \times S_{r}$

Where:

$$
\begin{aligned}
& R_{f}=\text { Resistance of fuel, cm of } \mathrm{H}_{2} \mathrm{O} \\
& T_{f}=\text { height of combustion chamber, } \mathrm{m} \\
& S_{r}=\text { specific resistance, } \mathrm{cm} \text { of water } / \mathrm{m} \text { of fuel }
\end{aligned}
$$

\section{Stove components description}

The experimental stove has a vertical Y-shaped structure consisting of two compartments namely, combustion chamber (fire box) with internal clay lining and an ash/char compartment. The cooking pot rests on the pot stand constructed of $1 / 4$ "mild steel rod while the combustion chamber consists of $518.6 \mathrm{~cm}^{3}$ of insulating clay lining encased by a mild steel plate designed to accommodate charcoal. A metal grate and screen $100 \times 100 \mathrm{~mm}$ (Figure 1) is provided as supports for fuel in the combustion chamber to allow for free flow from aspirated air and ash drop during combustion.

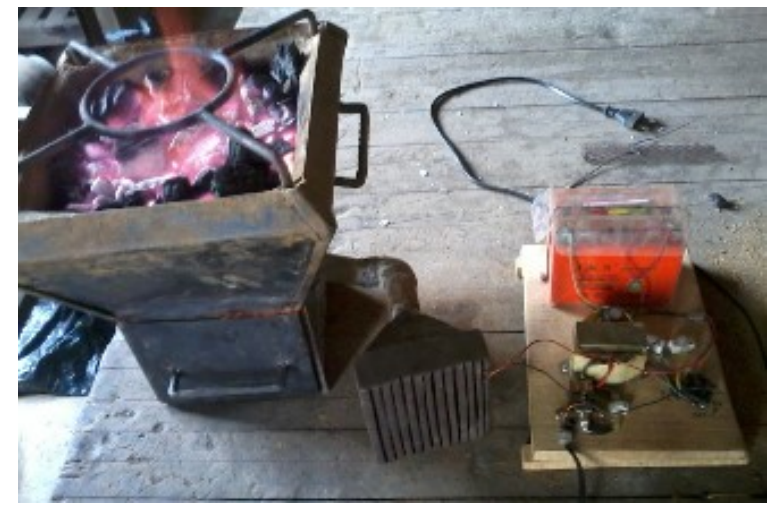

Figure 1: Experimental stove showing fan assembly and power pack

For efficient fuel combustion (charcoal), an air inlet duct was designed to incorporate a blower for supplementary air supply within the stove. Beneath the combustion chamber, is a $25 \mathrm{~mm}$ diameter air inlet pipe provided to connect the blower assembly to the stove. The ash collection tray is a light rectangular metal box which serves as storage for ash produced. It is located beneath the combustion chamber and is provided with a door for easy disposal of ash. The power pack is incorporated to supply aspirated air into the combustion chamber for efficient operation.

The power pack comprises of the following components and description:

The battery charging unit comprises of a $12 \mathrm{~V}$ step-down transformer which steps down the 220 Volts AC to 15 Volts AC output. This is connected to two diodes to convert the 15 volts AC into a 15 Volts DC to boost the battery voltage supply. The $12 \mathrm{~V} \mathrm{DC}$ battery with a power requirement of $4 \mathrm{Ah}$ provides residual power for the fan and lasts for $10 \mathrm{hrs}$ of operation at full charge. 


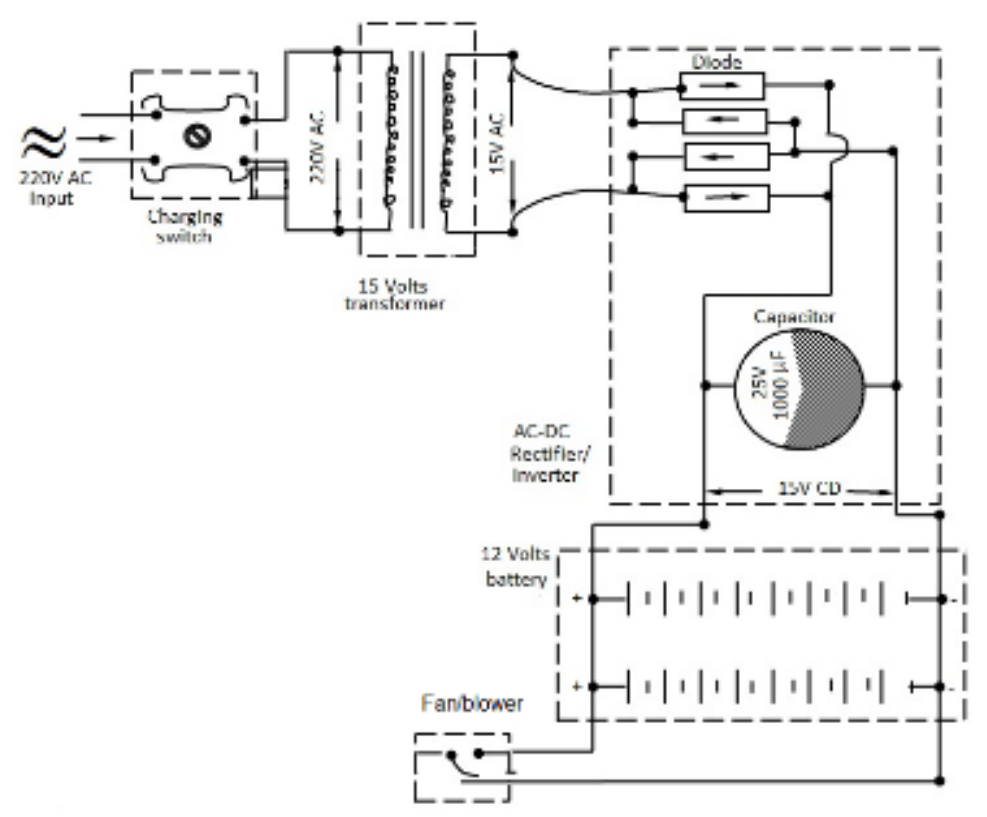

Figure 3: Charging circuit

The charging switch is a push type for easy of charging the battery when connected to the AC mains. The charging switch is located at the side of the battery casing. System charging is turned on by pressing down the switch to allow AC current flow into the primary coil winding of the transformer. A single full charge permits 10 cooking cycles and would need about $4 \mathrm{~h}$ of charging before fresh use. A single full charge can last about 5-6 cooking cycles and the charging time is an hour and a half.

The transformer comprises of a $12 \mathrm{~V}$ step-down transformer which steps down the 220 Volts AC to 15 Volts AC output while rectification is achieved by four diodes to convert the 15 volts AC into a 15 volts D.C and a 15 volt capacitor with $1000 \mu \mathrm{F}$ capacitance for smoothing the rough waves into small rippers and more linear form suitable for induction coil use. The fan selected is an axial flow type fan with $0.42 \mathrm{~m}^{3} / \mathrm{hr}$ air flow rate; consisting of a rotating assembly of blades and a rotor, or a runner contained within a housing or case to direct the airflow or increase safety by preventing objects from contacting the fan blades.
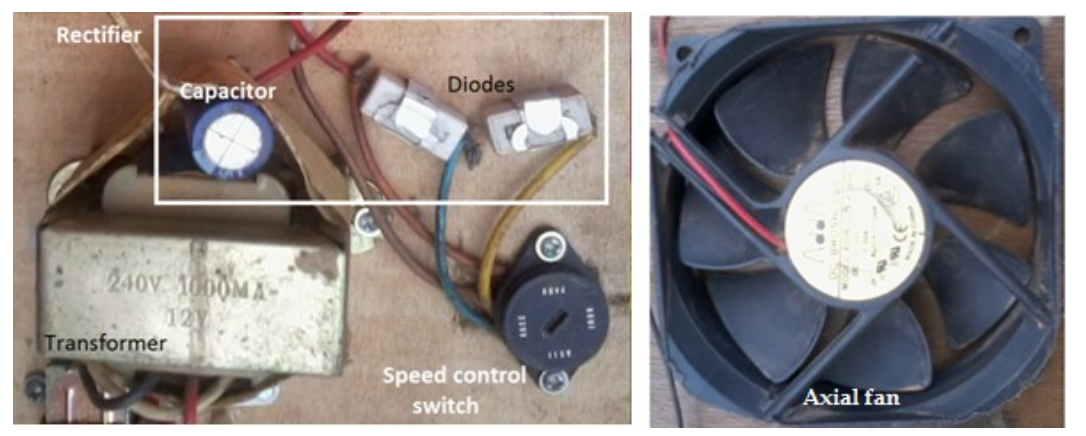

Figure 4: a) Rectification components, b) Axial fan

The speed is controlled by a 3-speed variable switch to vary the fan speed and air flow rates.

\section{Stove performance test materials and instrumentation}

The following materials and instruments are needed in testing the performance of the stove:

a. Fuels: Fuels used for the test include; charcoal.

b. Spring-scale balance: This device is used to measure the weight of rice husk fuel as well as the weight of food to be cooked and the weight of water to be boiled. 
c. A stop watch was used to monitor time of each of the activities (i.e. cooking and boiling) during the tests.

d. Volumetric flask and beaker used to measure the volume of water before and after the boiling test.

e. Test stoves: A conventional charcoal cook stove (Figure 5) which is popular among the rural households in South East Nigeria was used for control test.

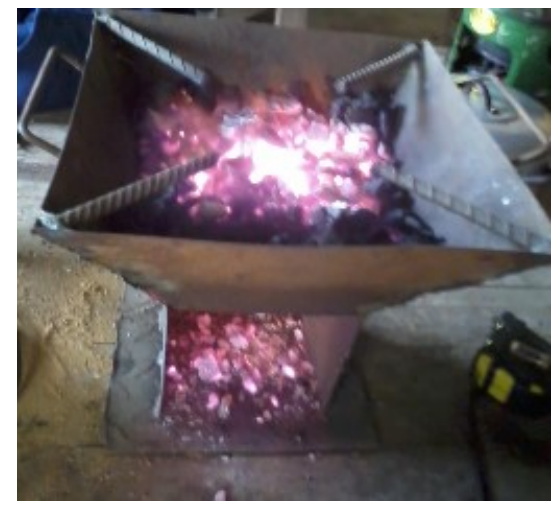

Figure 5: A conventional charcoal test stove, South East Nigeria

\section{Stove performance tests and variables}

In this study, the performance of the stove under simulated cooking conditions was intended using two of the standard stove test procedures to determine quantitative and qualitative information about the fuel and stove performance; i.e. water boiling test (WBT) and controlled cooking test (CCT) [14] Stewart (1987). The procedure and formulae employed in the calculation of parameters were based on the approaches used by [15, 16, and [17].

Some test parameters used in evaluating stove performance include:

a. Start-up time: This is the time required to ignite the fuel.

b. Operating time: This is the duration from the time the fuel lasted in burning.

c. Total operating time: This is the duration from the time the fuel is ignited until the fuel is completely burnt in the stove. Basically, it is the sum of the startup time and the operating time of the stove.

d. Time to consume fuel: This refers to the total time required to completely burn off the fuel in the combustion chamber. This includes the time to ignite the fuel plus the time to completely burn all the fuel in the stove. The density of the fuel $\left(\rho_{r n}\right)$, the volume of the combustion chamber $\left(V_{r}\right)$, and the fuel consumption rate (FCR) are the factors used in determining the total time to consume the fuel in the stove. As shown below, this can be computed using the formula,

$t=\frac{\rho_{r h} \times V_{r}}{F C R}$

Where:

$t$ = time required to consume the fuel, $\mathrm{hr}$

$V_{r}=$ volume of the combustion chamber, $\mathrm{m}^{3}$

$\rho_{r \grave{h}}=$ fuel density, $\mathrm{kg} / \mathrm{m}^{3}$

$\mathrm{FCR}=$ rate of consumption of fuel, $\mathrm{kg} / \mathrm{hr}$

e. Percentage char produced: This is the ratio of the amount of char produced to the amount of charcoal used. This can be computed using the formula presented by [12]. 
$\%$ Char $=\frac{\text { Weight of char, } \mathrm{kg}}{\text { Weight of fuel used }(\mathrm{kg})} \times 100$

\section{RESULTS AND DISCUSSION}

\section{Experimental setup}

The completed experimental setup showing special features of the stove is shown in Figure 1. Equal amount of some physical characteristics of fuel such as weight, volume were measured, and loaded into the two stoves and ignited. The first cooking experiment was carried out using yam. The pot containing water and yam was placed on the glowing fire and left to cook. When the cooking was properly done, the mass of the cooked yam and time to achieve cooking were recorded with the aid of a stopwatch. Also, the mass of the fuel remaining after cooking was also recorded. The process was repeated for each stove using rice.

The start-up time was set at zeros for both stoves. The ignition time of the fuels in the stove is between 3 to 5 minutes, which was lesser ( $3 \mathrm{~min} 38 \mathrm{sec}$ ) in the improved stove compare to traditional stove. This is due to low draft requirement of the fan which gives more air to start the fire in the improved stove. After igniting the fuel, the time required for the fuel to produce flammable gas is 2 to 5 minutes, depending on the quality of the fuel and the volume of air introduced into the fuel during firing. The emission of combustible gasses was observable in the traditional stove but not significant in the aspirated stove. Directly measured time-based parametric constants for each stove is shown in Table 1.

Table 1: Directly measured time-based parameters

\begin{tabular}{|c|c|c|}
\hline \multirow[b]{2}{*}{ Constant variables } & \multicolumn{2}{|c|}{ Stoves } \\
\hline & $\begin{array}{l}\text { Traditional } \\
\quad \text { (min) }\end{array}$ & Improved (min) \\
\hline Time at start of test & 0 & 0 \\
\hline Ignition time & 4.2 & 3.38 \\
\hline Time spent to consume fuel & 90 & 86 \\
\hline $\begin{array}{l}\text { Total operating time to consume } \\
\text { fuel }\end{array}$ & 94.3 & 89.6 \\
\hline Time spent for water to boil & 25.3 & $18 \mathrm{~min}$ \\
\hline Total operating time to boil water & 29.4 & 21.3 \\
\hline Water temp before test (amb.) & $30^{\circ} \mathrm{C}$ & $30^{\circ} \mathrm{C}$ \\
\hline Water temperature after test $\left({ }^{\circ} \mathrm{C}\right)$ & $100^{\circ} \mathrm{C}$ & $100^{\circ} \mathrm{C}$ \\
\hline Time spent in cooking rice & 60 & 45.8 \\
\hline Time spent in cooking yam & 34.2 & $50 \mathrm{~min}$ \\
\hline
\end{tabular}

Table 2 shows the test characteristics of the materials (stoves, fuel and food) used for the test and measured weights of test parameters before and after the tests. At full load, the combustion chamber 
can accommodate $0.8 \mathrm{~kg}$ of charcoal, and $0.6 \mathrm{~kg}$ of charcoal. At $75 \%$ loading, the amount of charcoal that can be loaded is $0.55 \mathrm{~kg} \mathrm{~kg}$, while at $50 \%$ load, it is $0.48 \mathrm{~kg}$.

Table 2: Weight of measured test parameters before and after the test (full load)

\begin{tabular}{lcccc}
\hline \multicolumn{1}{c}{ Sample weight } & \multicolumn{2}{c}{ Traditional stove (g) } & \multicolumn{2}{c}{ Improved stove (g) } \\
& Before test & After test & Before test & After test \\
\hline Weight of stove & 330 & $\mathbf{3 3 0}$ & 860 & 800 \\
Weight of charcoal & 800 & 100 & 800 & 100 \\
Weight of charcoal & 600 & 60 & 600 & 600 \\
Weight of charcoal + stove & 1130 & 398 & 940 & 868 \\
Weight of charcoal + stove & 930 & 390 & 1460 & 920 \\
Weight of water added & 1000 & 1000 & 1000 & 1000 \\
Weight of empty pots & 500 & 500 & 500 & 500 \\
Weight of pot + water & 1500 & 1450 & 1500 & 1460 \\
Weight of rice & 600 & 630 & 600 & 640 \\
Weight of yam & 776 & 680 & 775 & 680 \\
Weight of rice + pot & 1100 & 1130 & 1100 & 1140 \\
Weight of yam + pot & 1276 & 1700 & 1276 & 1700 \\
\hline
\end{tabular}

\section{Water boiling and cooking test (WBT) results}

The water-boiling and cooking time responses using a liter of water, (from $28{ }^{\circ} \mathrm{C}$ to $100{ }^{\circ} \mathrm{C}$ ), is shown in (Table 3). Boiling a liter of water with each stove would take $0.5 \mathrm{hr} / \mathrm{kg}$ and $0.36 \mathrm{hr} / \mathrm{kg}$ respectively while total specific time spent in boiling yam, with $11 \mathrm{tr}$ of water was $0.95 \mathrm{~kg} / \mathrm{hr}$ to $1.48 \mathrm{~kg} / \mathrm{hr}$ for traditional and improved stoves. In cooking rice, the traditional stove spent $1.17 \mathrm{hr} / \mathrm{kg}$ while improved stove spent $0.89 \mathrm{hr} / \mathrm{kg}$.

Table 3: Water-boiling and cooking tests time responses using a liter of water

\begin{tabular}{lcc}
\hline \multicolumn{1}{c}{ Performance variables } & $\begin{array}{c}\text { Traditional } \\
\text { stove }\end{array}$ & $\begin{array}{c}\text { Improved stove (full } \\
\text { load) }\end{array}$ \\
\hline $\begin{array}{l}\text { Total operating time to boil water } \\
\text { Total time spent in cooking yam }\end{array}$ & $\begin{array}{c}29 \mathrm{~min} 43 \mathrm{sec} \\
34 \mathrm{~min} 18 \mathrm{sec}\end{array}$ & $\begin{array}{c}\text { 5 min } 38 \mathrm{sec} \\
50 \mathrm{~min}\end{array}$ \\
$\begin{array}{l}\text { Total time spent in cooking rice } \\
\text { Specific time capacity in boiling }\end{array}$ & $1 \mathrm{hr} 40 \mathrm{~min}$ & $1 \mathrm{hr} 16 \mathrm{~min}$ \\
$\begin{array}{l}\text { water } \\
\text { Specific time capacity in cooking }\end{array}$ & $0.5 \mathrm{hr} / \mathrm{kg}$ & $0.36 \mathrm{hr} / \mathrm{kg}$ \\
$\begin{array}{l}\text { yam } \\
\begin{array}{l}\text { Specific time capacity in cooking } \\
\text { rice }\end{array}\end{array}$ & $1.17 \mathrm{hr} / \mathrm{kg}$ & $1.48 \mathrm{hr} / \mathrm{kg}$ \\
\hline
\end{tabular}


With these results, using $0.57 \mathrm{~kg}$ of charcoal in the improved stove is sufficient to provide energy to cook a household meal and excess energy can be used to heat water for other domestic purposes. Results of the operating performance of charcoal in the stoves in terms of fuel consumption rate, char produced, specific fuel combustion, burn rate, and specific burn rate is as shown in Table 4. The computed fuel consumption rate of the stoves ranges from 0.45 to $0.39 \mathrm{~kg}$ per hour for traditional and improved stove respectively. The percentage amount of char produced from the stove ranges from 12.5 to $28.8 \% \%$. This can be attributed to the higher amount of air supplied by the blower as when the reactor is fully loaded with rice husks.

Table 4: The operating performance of the stove

\begin{tabular}{|c|c|c|}
\hline Performance variables & Traditional stove & Improved stove \\
\hline Weight of charcoal consumed & $0.70 \mathrm{~kg}$ & $0.57 \mathrm{~kg}$ \\
\hline$\%$ char produced & $12.5 \%$ & $28.8 \%$ \\
\hline Equivalent charcoal consumed & $0.47 \mathrm{~kg}$ & $0.16 \mathrm{~kg}$ \\
\hline Total operating time to consume fuel & $\begin{array}{l}1 \mathrm{hr} \\
(1.57 \mathrm{hr})\end{array}$ & $1 \mathrm{hr} 29 \mathrm{~min} 38 \mathrm{sec}(1.48 \mathrm{hr})$ \\
\hline Fuel consumption rate (FCR) & $0.45 \mathrm{~kg} / \mathrm{hr}$ & $0.39 \mathrm{~kg} / \mathrm{hr}$ \\
\hline Specific fuel consumption & 1.17 & 0.95 \\
\hline Burn rate $\left(\mathrm{r}_{\mathrm{cb}}\right)$ & $0.314 \mathrm{~kg} / \mathrm{hr}$ & $0.122 \mathrm{~kg} / \mathrm{hr}$ \\
\hline Specific burn rate (SBR) & $0.874 \mathrm{~kg} / \mathrm{m}^{2}-\mathrm{hr}$ & $0.755 \mathrm{~kg} / \mathrm{m}^{2}-\mathrm{hr}$ \\
\hline
\end{tabular}

The stoves power performance characteristics are as shown in Table 12. With the power input of $2.26 \mathrm{~kW}(0.691 \mathrm{Kw} / \mathrm{hr})$ and overall thermal efficiency of $36.74 \%$ for the improved stove, the stove is thermally efficient more than the traditional stove.

Table 5: Power output and efficiency of the stove

\begin{tabular}{|c|c|c|c|}
\hline Stove & $\begin{array}{c}\text { Power input } \\
(\mathrm{kW} / \mathrm{hr})\end{array}$ & $\begin{array}{c}\text { Power output } \\
(\mathrm{kW} / \mathrm{hr})\end{array}$ & $\begin{array}{c}\text { Thermal } \\
\text { efficiency }(\%)\end{array}$ \\
\hline Traditional & 0.043 & 0.231 & 72.07 \\
\hline Improved & 0.038 & 0.691 & 84.30 \\
\hline
\end{tabular}

\section{CONCLUSION}

An air aspirated charcoal stove was developed, constructed and tested in comparison with a conventional charcoal stove. In the design, parameters considered include air flow rate, superficial velocity, insulation, and power thermal efficiency and emission rate. The incorporation of aspirated air into the combustion chamber increased the thermal efficiency (by $12.23 \%$ ), reduce the fuel consumption rate (by 13.33\%), reduced charcoal usage (by 66\%) and reduced gas emission which is in line with the paradigm shift from fuel-efficient stoves to emission efficient stoves. There exists a comparative advantage between an improved charcoal stove available in the market and the aspirated stove when considering comfort, ease of operation and environmental friendliness as tradeoff to cost. The average of cost of improved stoves ranges between N500.00 and N1, 400.00 while the cost of the aspirated stove (inclusive the stove and the power pack) is estimated at N2, 200.00 . 


\section{References}

[1]. Bello, S. R. and Onilude M. A. Characterization of Conventional Cooking Stoves in South Eastern Nigeria. International letters of Natural Sciences Vol 18 (2014) 89-99 doi:10.18052/www.scipress.com/ILNS.18.89 http://www.scipress.com/ILNS.18.89 ISSN 2300-9675

[2]. George, R. Commercialization of technology for domestic cooking applications in biomass energy systems. Venkata Ramana, P.; and Srinivas, S.N. (Eds.). Tata Energy Research Institute (TERI), New Delhi, India. (1997)

[3]. Bello, R. S., Okafor E. C., Ezebuilo C. N, Bello M. B. \& Umahi. Cookstove technologies and environmental impacts in the South-eastern Nigeria. Bello R. S. Balogun R. B. \& Okereke S. N. (Eds), (2013). Sustainable Environmental Management: Issues \& Projections Pub Createspace. ISBN-13: 978-149-285-349-7 Url: https://tsw.createspace.com/title/ (2013) Pg 216-239.

[4]. Ernestine Andandoh Tangang Yuntenwi, 2008. Improved Biomass Cookstoves - A Strategy towards Mitigating Indoor Air Pollution and Deforestation. A case study of the North West Province of Cameroon. A PhD thesis, Faculty of Environmental Sciences and Process Engineering, Brandenburg University of Technology in Cottbus

[5]. WHO. Evaluating Household Energy and Health Interventions: A Catalogue of Methods (Geneva: World Health Organization, 2008), who.int/indoor air/publications/methods/en/index.html (2008).

[6]. Agency for International Development. Berkeley Air Monitoring Group, Evaluation of Manufactured Wood-Burning Stoves in Dadaab Refugee Camps, Kenya (Washington, DC: U.S. Agency for International Development, 2010), usaid.gov/our_work/economic_growth_and_trade/energy/publications/

Dadaab_wood_stove_evaluation.pdf

[7]. Baldwin, S.F. Biomass Stoves: Engineering Design, Development, and Dissemination. Center for Energy and Environmental Studies: Princeton, NJ. (1986) p. 287.

[8]. Bryden Mark, Dean Still, Peter Scott. Design Principles for Wood Burning Cook Stoves (London: Shell Foundation; Washington DC: U.S. Environmental Protection Agency,), (2006) http://bioenergylists.org/stovesdoc/Pcia/Design\%20Principles\%20for\%20Wood\%20Burning $\% 20$ Cookstoves.pdf.

[9]. Smith-Sivertsen Tone, Esperanza Díaz, Dan Pope, -Effect of Reducing Indoor Air Pollution on Women's Respiratory Symptoms and Lung Function: The RESPIRE Randomized Trial, Guatemala,\| American Journal of Epidemiology 170, no. 2 (2009): 211-220, http://aje.oxfordjournals.org/content/170/2/211.abstract.

[10]. James Jetter and Peter Kariher, -Solid-Fuel Household Cook Stoves: Characterization of Performance and Emissions, Biomass and Bioenergy 33, no. 2 (2009): 294-305, http://dx.doi.org/10.1016/j.biombioe.2008.05.014.

[11]. Adamkiewicz Gary et al., WHO Guidelines for Indoor Air Quality: Selected Pollutants (Copenhagen: World Health Organization, 2010), euro.who.int/_data/assets/pdf_file/0009/128169/e94535.pdf.

[12]. Belonio A. T. Rice husk gas stove handbook. Appropriate Technology Center, Dept of Agric Engr \&

[13]. John Zactruba, 2012. How Much Air is required to Burn Coal. Ed: Lamar Stonecypher. http://www.brighthubengineering.com/power-plants/20189-burning-coal-how-much-air-isrequired/ updated: 12/12/2014 
[14]. Stewart, W. Improved Wood, Waste and Charcoal Burning Stoves. A Practical Manual. Intermediate Technology Publications, Covent Garden, London, UK. (1987)

[15]. FAO, 1990. The briquetting of agricultural wastes for fuel. Food and Agriculture Organization of the United Nations.

[16]. Ahuja, D. F; Joshi, V., Smith, K.R. and Venkataranman, C. Thermal Performance and Emission Characteristic of Unvented Biomass-Burning Cookstove. Standard Methods for Evaluation Biomass. (1997) 10:12.

[17]. Olorunisola, A.O. "Efficiency of two Nigerian Cooking Stoves in Handling Corn-Cob briquettes". Nigerian Journal of Renewable Energy. (1999) Vol. 7, Nos. 1 \&2 pp 31-34. 